\title{
Sediminibacillus albus sp. nov., a moderately halophilic, Gram-positive bacterium isolated from a hypersaline lake, and emended description of the genus Sediminibacillus Carrasco et al. 2008
}

Correspondence

Yanfen Xue

xueyf@im.ac.cn
Xiaowei Wang, ${ }^{1,2}$ Yanfen $\mathrm{Xue}^{1}$ and Yanhe $\mathrm{Ma}^{1}$

\author{
${ }^{1}$ State Key Laboratory of Microbial Resources, Institute of Microbiology, Chinese Academy of \\ Sciences, 100101 Beijing, PR China \\ ${ }^{2}$ Graduate University of the Chinese Academy of Sciences, 100049 Beijing, PR China
}

Moderately halophilic bacteria that can grow optimally in media containing salt concentrations of $3-15 \%(\mathrm{w} / \mathrm{v})$ make up an extremely heterogeneous group of microorganisms that are distributed widely in diverse saline habitats such as salt lakes, brines, saline soils, soda lakes, salted foods and some other hypersaline environments (Kushner, 1985; Ventosa et al., 1998). The genus Sediminibacillus, which belongs to this moderately halophilic group of bacteria, was first proposed by Carrasco et al. (2008) to accommodate moderately halophilic, facultatively anaerobic, Gram-positive, rod-shaped bacteria related phylogenetically to members of the genera Thalassobacillus and Halobacillus within the family Bacillaceae. The genus Sediminibacillus comprises the single species Sediminibacillus halophilus, the type strain of which was isolated from sediment of Lake Erliannor in Inner Mongolia, China. During the course of an investigation of the diversity of halophilic micro-organisms in

The GenBank/EMBL/DDBJ accession number for the $16 \mathrm{~S}$ rRNA gene sequence of strain $\mathrm{NHBX}^{\top}$ is $\mathrm{DQ989634}$.

A scanning electron micrograph of cells of strain $\mathrm{NHBX} 5^{\top}$ and the cellular fatty acid profiles of strain $\mathrm{NHBX} 5^{\top}$ and $S$. halophilus $E N 8 d^{\top}$ are available as supplementary material with the online version of this paper.
Nanhuobuxun salt lake ( $\left.36^{\circ} 43^{\prime} 14.7^{\prime \prime} \mathrm{N} 95^{\circ} 42^{\prime} 41^{\prime \prime} \mathrm{E}\right)$, a spore-forming, Gram-positive, moderately halophilic strain $\left(\mathrm{NHBX}^{\mathrm{T}}{ }^{\mathrm{T}}\right)$ was isolated that appeared to represent a novel species of the genus Sediminibacillus. In this study, the phenotypic, chemotaxonomic and genotypic characteristics of this moderately halophilic strain are presented.

Nanhuobuxun salt lake is located at $2700 \mathrm{~m}$ above sea level in the south-east Bieletan region of Qaidam basin of Qinghai province, China. It is a very typical chloride saline lake, with a high salinity of $31.8 \%$ and a near-neutral $\mathrm{pH}$ of 6.7. Strain $\mathrm{NHBX}^{\mathrm{T}}$ was isolated from a sediment sample of Nanhuobuxun salt lake by enrichment in liquid SG medium (Sehgal \& Gibbons, 1960) at $37{ }^{\circ} \mathrm{C}$ followed by serial dilution plating of enrichment cultures on SG agar medium until a pure colony was obtained. The SG medium ( $\mathrm{pH}$ adjusted to 7.0-7.2 with $1 \mathrm{M} \mathrm{NaOH}$ before autoclaving at $121{ }^{\circ} \mathrm{C}$ for $\left.20 \mathrm{~min}\right)$ contained the following $\left(\mathrm{g} \mathrm{l}^{-1}\right)$ : Casamino acids (Difco), 7.5; yeast extract (Difco), 10.0; sodium glutamate, 1.0; trisodium citrate, 3.0; $\mathrm{MgSO}_{4} .7 \mathrm{H}_{2} \mathrm{O}, 20.0 ; \mathrm{KCl}, 2.0 ; \mathrm{NaCl}, 200 ; \mathrm{FeSO}_{4} \cdot 7 \mathrm{H}_{2} \mathrm{O}$, 0.036; and $\mathrm{MnCl}_{2} .4 \mathrm{H}_{2} \mathrm{O}, 0.00036$. Strain $\mathrm{NHBX}^{\mathrm{T}}$ was cultured routinely on growth medium (GM; $\mathrm{pH}$ 7.0-7.5) containing the following $\left(\mathrm{g} \mathrm{l}^{-1}\right)$ : Casamino acids (Difco), 
5.0; yeast extract (Difco), $5.0 ; \mathrm{NaCl}, 70 ; \mathrm{MgSO}_{4} .7 \mathrm{H}_{2} \mathrm{O}, 5.0$; $\mathrm{KCl}, 2.0 ; \mathrm{FeSO}_{4} .7 \mathrm{H}_{2} \mathrm{O}, 0.036$; and $\mathrm{MnCl}_{2} .4 \mathrm{H}_{2} \mathrm{O}, 0.00036$. Strain $\mathrm{NHBX}^{\mathrm{T}}$ was maintained in this medium supplemented with $30 \%(\mathrm{v} / \mathrm{v})$ glycerol at $-80{ }^{\circ} \mathrm{C}$ for long-term preservation. S. halophilus CGMCC $1.6199^{\mathrm{T}}$ was obtained from the China General Microbiological Culture Collection and used as a reference strain for comparative phenotypic studies and DNA-DNA hybridization tests. The recommended medium and culture conditions for growth of this bacterium were used.

The morphology, pigmentation and size of colonies were observed on GM agar after $48 \mathrm{~h}$ incubation at $37^{\circ} \mathrm{C}$. Cell morphology and motility were examined using light and scanning electron microscopes. Gram-type was determined by the staining method (Doetsch, 1981) and the $\mathrm{KOH}$ lysis method (Gregersen, 1978). The range of $\mathrm{NaCl}$ concentration for growth was determined in modified GM medium with different $\mathrm{NaCl}$ concentrations $(0,1,3,5,7,9,12,16,20,22$ and $25 \%, \mathrm{w} / \mathrm{v})$. The $\mathrm{pH}$ range for growth was tested at intervals of $0.5 \mathrm{pH}$ unit in liquid GM medium buffered with $20 \mathrm{mM}$ MES ( $\mathrm{pH}$ 5.0-6.5), PIPES ( $\mathrm{pH}$ 6.5-7.5), HEPES ( $\mathrm{pH}$ 7.0-8.0), Tricine ( $\mathrm{pH} 7.5-9.0)$ and CHES ( $\mathrm{pH} 9.0$ 10.0). Growth at different temperatures $(4,10,15,20,25,30$, $37,40,45$ and $50{ }^{\circ} \mathrm{C}$ ) was determined in GM medium. General biochemical tests (including the presence of oxidase and catalase, urease activity, $\mathrm{H}_{2} \mathrm{~S}$ production, nitrate reduction, $\mathrm{NH}_{3}$ production, citrate utilization, indole production, Voges-Proskauer reaction, methyl red test and hydrolysis of Tweens 20,40, 60 and 80 , gelatin, aesculin, starch and casein) were performed according to previously described methods (Smibert \& Krieg, 1981; Ventosa et al., 1982). Anaerobic growth in the presence of nitrate was tested as described previously (Mancinelli \& Hochstein, 1986). The utilization of glucose by oxidation or fermentation and of various substrates as sole carbon and energy sources were determined as described previously (Ventosa $e t$ al., 1982). Unless otherwise indicated, all tests were carried out in triplicate in media containing $7 \%(\mathrm{w} / \mathrm{v}) \mathrm{NaCl}$ at $37^{\circ} \mathrm{C}$. Growth was monitored by turbidity at $\mathrm{OD}_{600}$. API $50 \mathrm{CH}$ test strips (Analytab Products; bioMérieux) were also used to examine assimilation of carbohydrates and the production of acid as recommended by the manufacturer, but with a modification that the suspension medium supplied by bioMérieux and used to resuspend cells of strain $\mathrm{NHBX}^{\mathrm{T}}$ was supplemented with $7 \%(\mathrm{w} / \mathrm{v}) \mathrm{NaCl}$. Susceptibility to antimicrobial agents was tested by spreading exponential-phase cultures on GM agar medium plates with absorbent paper discs impregnated with antimicrobial agents. Zones of inhibition were determined after incubation at $37^{\circ} \mathrm{C}$ for 3 days.

Cells of strain $\mathrm{NHBX}^{\mathrm{T}}$ were aerobic rods and formed terminal ellipsoidal or spherical endospores after $48 \mathrm{~h}$ incubation at $37{ }^{\circ} \mathrm{C}$ on GM agar supplemented with $5 \mathrm{mg}$ $\mathrm{MnSO}_{4} 1^{-1}$ (see Supplementary Fig. S1, available in IJSEM Online). Anaerobic growth of strain $\mathrm{NHBX}^{\mathrm{T}}$ was not detected in the presence of glucose or nitrate. Nitrate reduction by strain $\mathrm{NHBX}^{\mathrm{T}}$ under aerobic conditions was not observed. Strain $\mathrm{NHBX}^{\mathrm{T}}$ utilized glucose by oxidation. It was moderately halophilic, growing in modified GM medium with $0-22 \%(w / v) ~ N a C l$ (optimally at $7 \%$ ). Other phenotypic features are presented in the species description.

Preparation of the cell wall and determination of peptidoglycan structure were performed by the methods described by Schleifer \& Kandler (1972) with the modification that TLC on cellulose sheets was used instead of paper chromatography. The amino acid composition of the cell wall hydrolysate was determined using one-dimensional descending film chromatography on cellulose sheets. Respiratory quinones were extracted according to the method of Collins et al. (1977) and analysed by reversedphase HPLC (Groth et al., 1996). Polar lipids were extracted and identified by one-dimensional TLC followed by spraying with the appropriate detection reagent (Kates, 1986). Fatty acids were extracted, methylated and analysed by GC using the standard Sherlock MIDI (Microbial Identification) system (Sasser, 1990; Kämpfer \& Kroppenstedt, 1996). Genomic DNA of strain NHBX5 ${ }^{\mathrm{T}}$ was extracted using the method described by Marmur (1961). Cell mass used for procedures mentioned above was obtained by cultivating the strain at $37^{\circ} \mathrm{C}$ on GM agar. The genomic DNA G $+\mathrm{C}$ content was determined by the thermal denaturation method according to Marmur \& Doty (1962).

Strain $\mathrm{NHBX}^{\mathrm{T}}$ possessed peptidoglycan type Al $\gamma$ with meso-diaminopimelic acid as the diagnostic diamino acid. The isoprenoid quinones detected in strain $\mathrm{NHBX}^{\mathrm{T}}$ were MK-7 (96.9\%) and MK-6 (3.1\%). The cellular polar lipids were diphosphatidylglycerol, phosphatidylglycerol and a glycolipid. The major fatty acids $(>1 \%)$ in cells of strain NHBX5 $^{\mathrm{T}}$ were branched anteiso- $\mathrm{C}_{15: 0}(45.1 \%)$, anteiso$\mathrm{C}_{17: 0}(30.7 \%)$, iso- $\mathrm{C}_{15: 0}(9.0 \%)$, iso- $\mathrm{C}_{16: 0}(4.8 \%)$ and iso- $\mathrm{C}_{17: 0}(1.4 \%)$ and straight-chain $\mathrm{C}_{16: 0}(3.5 \%)$. The genomic DNA G+C content of strain $\mathrm{NHBX}^{\mathrm{T}}$ was $44.9 \mathrm{~mol} \%$. These chemotaxonomic data are in accordance with those described for the genus Sediminibacillus.

The 16S rRNA gene was amplified by PCR using universal bacterial primers (8F and 1495R) as described previously (Duckworth et al., 1996). The almost-complete nucleotide sequence (1468 bp) was determined by direct sequencing and compared with available $16 \mathrm{~S}$ rRNA gene sequences in GenBank by using the BLAST program. Multiple alignment with sequences from closely related species was performed by using the program CLUSTAL_x (Thompson et al., 1997). Ambiguous and unalignable bases were manually omitted and then the phylogenetic tree was constructed from the evolutionary distance matrix calculated by using the neighbour-joining, minimum-evolution and maximumparsimony methods in the program MEGA version 3.1 (Kumar et al., 2004). The robustness of the resultant tree topology was evaluated by bootstrap resampling analysis with 1000 replicates (Felsenstein, 1985). A comparative analysis using $16 \mathrm{~S}$ rRNA gene sequences available in the database revealed that strain $\mathrm{NHBX}^{\mathrm{T}}$ was most closely 
related to $S$. halophilus $\mathrm{EN} 8 \mathrm{~d}^{\mathrm{T}}$, with a sequence similarity of $98.6 \%$, and had less than $96.7 \%$ gene sequence similarity to other known species of the closely related genera, such as 94.4-96.7\% to members of the genus Virgibacillus, 95.2$96.3 \%$ to members of the genus Halobacillus, $95.2 \%$ to the type strain of Thalassobacillus devorans (the sole species of the genus Thalassobacillus), 94.4-95.3\% to members of the genus Gracilibacillus and $93.9-95.2 \%$ to members of the genus Amphibacillus. The phylogenetic tree (Fig. 1) based on the neighbour-joining method showed that strain $\mathrm{NHBX}^{\mathrm{T}}$ clustered with S. halophilus EN8d ${ }^{\mathrm{T}}$ with significant bootstrap support $(100 \%)$. Topologies of phylogenetic trees constructed using the minimum-evolution and maximum-parsimony algorithms were similar to that of the tree constructed using neighbour-joining analysis (data not shown). DNA-DNA hybridization was performed by the spectrophotometric renaturation rate method (Huß et al., 1983; De Ley et al., 1970) to determine the level of genomic DNA relatedness between strain $\mathrm{NHBX}^{\mathrm{T}}$ and $S$. halophilus CGMCC $1.6199^{\mathrm{T}}$. The level of DNA-DNA relatedness between strain $\mathrm{NHBX}^{\mathrm{T}}$ and $S$. halophilus CGMCC $1.6199^{\mathrm{T}}$ was $34.6 \%$ (mean of three independent experiments, which did not differ by more than $4 \%$ ). This low value indicates that strain $\mathrm{NHBX}^{\mathrm{T}}$ is not related genotypically to S. halophilus CGMCC $1.6199^{\mathrm{T}}$.

Several phenotypic features that also distinguish strain NHBX $5^{\mathrm{T}}$ from S. halophilus EN8d $\mathrm{d}^{\mathrm{T}}$ are shown in Table 1. Strain $\mathrm{NHBX}^{\mathrm{T}}$ was strictly aerobic, whereas $S$. halophilus EN8d ${ }^{\mathrm{T}}$ was able to grow under anaerobic conditions. Cells of $S$. halophilus EN8d ${ }^{\mathrm{T}}$ did not display endospores, whereas strain $\mathrm{NHBX}^{\mathrm{T}}$ easily formed ellipsoidal or spherical endospores, causing swelling of sporangia. Differences in other features such as pigmentation, range of temperature for growth, nitrate reduction and $\mathrm{H}_{2} \mathrm{~S}$ production and the genomic DNA G $+\mathrm{C}$ content enable strain $\mathrm{NHBX}^{\mathrm{T}}$ to be distinguished from S. halophilus EN8d ${ }^{\mathrm{T}}$.

Therefore, on the basis of the polyphasic evidence above, strain $\mathrm{NHBX}^{\mathrm{T}}$ represents a novel species of the genus Sediminibacillus. The name Sediminibacillus albus sp. nov. is proposed for this species. Based on differential phenotypic characteristics of strain $\mathrm{NHBX}^{\mathrm{T}}$ not reported in the description of the genus Sediminibacillus by Carrasco et al. (2008), an emended description of the genus is presented.

\section{Emended description of the genus Sediminibacillus Carrasco et al. 2008}

The description of the genus Sediminibacillus is as given by Carrasco et al. (2008) with the following amendments. Endospores may be formed terminally in swollen sporangia or not be observed. Cells are aerobic or facultatively anaerobic. Nitrate may or may not be reduced. The genomic DNA G+C content ranges from 44.9 to $47.5 \mathrm{~mol} \%$. The type species is Sediminibacillus halophilus.

\section{Description of Sediminibacillus albus sp. nov.}

Sediminibacillus albus (al'bus. L. masc. adj. albus white).

Cells are Gram-positive-staining rods $(0.4-0.6 \times 2.0$ $4.0 \mu \mathrm{m}$ ), strictly aerobic, spore-forming and motile by means of peritrichous flagella. Ellipsoidal or spherical endospores are formed terminally in swollen sporangia. Cells occur singly, in pairs or in short chains. After cultivation on GM agar at $37{ }^{\circ} \mathrm{C}$ for 2 days, colonies are circular, white, opaque and slightly convex, $1.5-2.0 \mathrm{~mm}$ in diameter. Grows at $10-45{ }^{\circ} \mathrm{C}$ (optimum $37{ }^{\circ} \mathrm{C}$ ) and at $\mathrm{pH}$ 5.5-9.0 (optimum $\mathrm{pH}$ 7.5). Can grow at $\mathrm{NaCl}$ concentrations between 0 and $22 \%(\mathrm{w} / \mathrm{v})$ with optimum growth at $7 \%(\mathrm{w} / \mathrm{v}) \mathrm{NaCl}$. Positive for oxidase, catalase, methyl red reaction, $\mathrm{H}_{2} \mathrm{~S}$ production from thiosulfate, $\mathrm{NH}_{3}$ production from peptone, indole production, citrate utilization and hydrolysis of gelatin, aesculin and Tweens 20, 40, 60 and 80, but is negative for the Voges-Proskauer reaction, nitrate reduction, urease production and casein hydrolysis. Produces acids from D-glucose by oxidation. Produces acid in the API 50CH gallery from glycerol, Larabinose, D-xylose, D-glucose, D-galactose, D-fructose, Dmannose, L-sorbose, L-rhamnose, mannitol, amygdalin, arbutin, salicin, starch, cellobiose, maltose, lactose, melibiose, trehalose, gentiobiose and $N$-acetylglucosamine, but not from D-sorbitol, sucrose, erythritol, D-ribose, turanose, D-arabinose, D-adonitol, methyl $\beta$-D-xylopyranoside, dulcitol, inositol, methyl- $\alpha$-D-glucopyranoside, inulin, melezi-

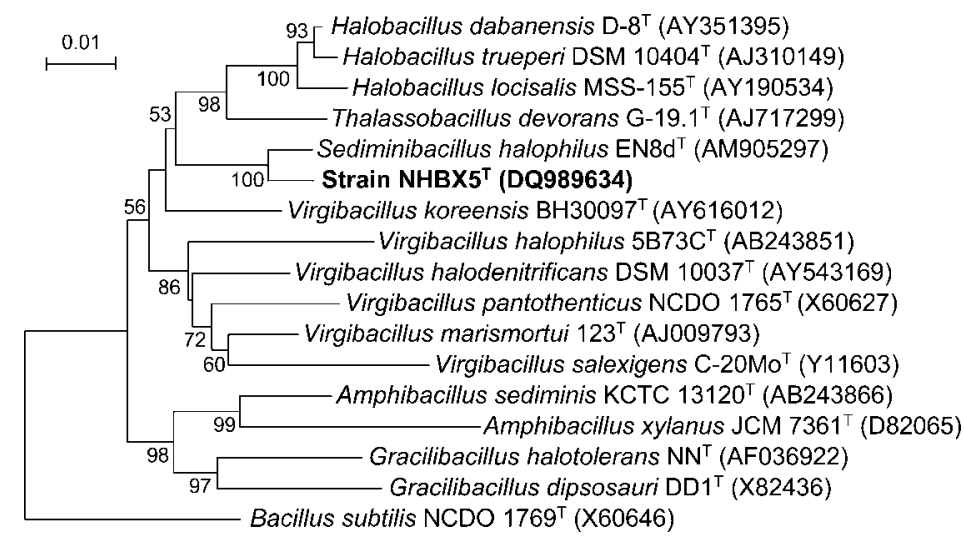

Fig. 1. Phylogenetic tree showing the relationship between strain $\mathrm{NHBX}^{\top}$ and related strains based on 16S rRNA gene sequences. Numbers at nodes represent the levels of bootstrap support (\%) based on a neighbourjoining analysis of 1000 resampled datasets. Accession numbers of nucleotide sequences are given in parentheses. Bar, $1 \%$ sequence divergence. 
Table 1. Characteristics that distinguish strain $\mathrm{NHBX}^{\top}$ from $S$. halophilus EN8d ${ }^{\top}$

Data for S. halophilus EN8d ${ }^{\mathrm{T}}$ were taken from Carrasco et al. (2008). Both strains are rod-shaped, motile and positive for Gram-staining reaction, oxidase, catalase and the Voges-Proskauer reaction. Both strains hydrolyse aesculin, gelatin and Tween 80 , but not casein or starch. Both strains produce acid from D-glucose, D-galactose, D-mannose, trehalose, D-fructose and glycerol. The following compounds are utilized as sole carbon and energy sources: D-arabinose, cellobiose, D-galactose and D-lactose. The following compounds are not utilized as sole carbon and energy sources: D-mannose and D-sorbitol. The following compounds are not used as sole carbon, nitrogen and energy sources: L-arginine, aspartic acid, L-cysteine, glutamic acid, L-methionine and phenylalanine. +, Positive; -, negative; ND, not observed.

\begin{tabular}{|c|c|c|}
\hline Characteristic & Strain NHBX $5^{\mathrm{T}}$ & S. halophilus EN8d ${ }^{\mathrm{T}}$ \\
\hline Colony pigmentation & White & Cream \\
\hline Size of cells $(\mu \mathrm{m})$ & $0.4-0.6 \times 2.0-4.0$ & $0.9 \times 1.5-7.0$ \\
\hline Spore formation & + & $\mathrm{ND}$ \\
\hline Anaerobic growth & - & + \\
\hline $\mathrm{pH}$ range for growth & $5.5-9.0$ & $5.0-9.5$ \\
\hline Temperature range for growth $\left({ }^{\circ} \mathrm{C}\right)$ & $10-45$ & $20-55$ \\
\hline \multicolumn{3}{|l|}{$\mathrm{NaCl}$ concentration for growth $(\%, w / v)$} \\
\hline Range & $0-22$ & $0-20$ \\
\hline Optimum & 7.0 & $5.0-7.5$ \\
\hline Indole test & + & - \\
\hline Nitrate reduction & - & + \\
\hline $\mathrm{H}_{2} \mathrm{~S}$ production & + & - \\
\hline $\begin{array}{l}\text { Utilization of maltose, melibiose, raffinose and D-xylose as sole } \\
\text { carbon and energy sources }\end{array}$ & + & - \\
\hline $\begin{array}{l}\text { Utilization of L-alanine and L-serine as sole carbon, nitrogen and } \\
\text { energy sources }\end{array}$ & - & + \\
\hline DNA G $+\mathrm{C}$ content $(\mathrm{mol} \%)$ & 44.9 & 47.5 \\
\hline
\end{tabular}

tose, raffinose, glycogen, xylitol, L-xylose, D-tagatose, D- or L-fucose, D- or L-arabitol, gluconate, 5- or 2-ketogluconate or methyl $\alpha$-D-mannopyranoside. The following compounds are not used as sole carbon, nitrogen and energy sources: L-alanine, L-serine, L-arginine, aspartic acid, Lcysteine, glutamic acid, L-methionine and phenylalanine. Susceptible to ciprofloxacin $(5 \mu \mathrm{g})$, chloramphenicol $(30 \mu \mathrm{g})$, kanamycin $(30 \mu \mathrm{g})$, erythromycin $(15 \mu \mathrm{g})$, tetracycline $(30 \mu \mathrm{g})$, ampicillin $(10 \mu \mathrm{g})$, novobiocin $(5 \mu \mathrm{g})$, rifampicin $(5 \mu \mathrm{g})$, vancomycin $(30 \mu \mathrm{g})$ and penicillin $(5 \mu \mathrm{g})$, but resistant to norfloxacin $(10 \mu \mathrm{g})$, bacitracin $(0.04 \mathrm{U})$ and streptomycin $(10 \mu \mathrm{g})$. The major cellular fatty acids are anteiso- $\mathrm{C}_{15: 0}$ and anteiso- $\mathrm{C}_{17: 0}$. The major cellular polar lipids are diphosphatidylglycerol, phosphatidylglycerol and a glycolipid. The major menaquinone type is MK-7. The cell-wall peptidoglycan contains mesodiaminopimelic acid as the diagnostic diamino acid.

The type strain is $\mathrm{NHBX}^{\mathrm{T}}$ (=DSM $19340^{\mathrm{T}}=\mathrm{CGMCC}$ $\left.1.6502^{\mathrm{T}}\right)$, isolated from a sediment sample of Lake Nanhuobuxun in Qinghai province, China. The genomic DNA G + C content of strain $\mathrm{NHBX}^{\mathrm{T}}$ is $44.9 \mathrm{~mol} \%\left(T_{\mathrm{m}}\right.$ method).

\section{Acknowledgements}

This work was supported by grants from the Ministry of Science and Technology of China (973 programs 2003CB716001 and 2004CB719605; 863 programs 2006AA020201 and 2007AA021306) and the Chinese Academy of Sciences (Knowledge Innovation program, KSCX2-YW-G-011).

\section{References}

Carrasco, I. J., Márquez, M. C., Xue, Y., Ma, Y., Cowan, D. A., Jones, B. E., Grant, W. D. \& Ventosa, A. (2008). Sediminibacillus halophilus gen. nov., sp. nov., a moderately halophilic, Gram-positive bacterium from a hypersaline lake. Int J Syst Evol Microbiol 58, 1961-1967.

Collins, M. D., Pirouz, T., Goodfellow, M. \& Minnikin, D. E. (1977). Distribution of menaquinones in actinomycetes and corynebacteria. J Gen Microbiol 100, 221-230.

De Ley, J., Cattoir, H. \& Reynaerts, A. (1970). The quantitative measurement of DNA hybridization from renaturation rates. Eur $J$ Biochem 12, 133-142.

Doetsch, R. N. (1981). Determinative methods of light microscopy. In Manual of Methods for General Bacteriology, pp. 21-33. Edited by P. Gerhardt, R. G. E. Murray, R. N. Costilow, E. W. Nester, W. A. Wood, N. R. Krieg \& G. B. Philips. Washington, DC: American Society for Microbiology.

Duckworth, A. W., Grant, W. D., Jones, B. E. \& van Steenbergen, R. (1996). Phylogenetic diversity of soda lake alkaliphiles. FEMS Microbiol Ecol 19, 181-191.

Felsenstein, J. (1985). Confidence limits on phylogenies: an approach using the bootstrap. Evolution 39, 783-791.

Gregersen, T. (1978). Rapid method for distinction of Gram-negative from Gram-positive bacteria. Eur J Appl Microbiol Biotechnol 5, 123-127.

Groth, I., Schumann, P., Weiss, N., Martin, K. \& Rainey, F. A. (1996). Agrococcus jenensis gen. nov., sp. nov., a new genus of actinomycetes with diaminobutyric acid in the cell wall. Int J Syst Bacteriol 46, 234-239. 
Huß, V. A. R., Festl, H. \& Schleifer, K. H. (1983). Studies on the spectrophotometric determination of DNA hybridization from renaturation rates. Syst Appl Microbiol 4, 184-192.

Kämpfer, P. \& Kroppenstedt, R. M. (1996). Numerical analysis of fatty acid patterns of coryneform bacteria and related taxa. Can J Microbiol 42, 989-1005.

Kates, M. (1986). Techniques of Lipidology, 2nd edn. Amsterdam: Elsevier.

Kumar, S., Tamura, K. \& Nei, M. (2004). MEGA3: integrated software for molecular evolutionary genetics analysis and sequence alignment. Brief Bioinform 5, 150-163.

Kushner, D. J. (1985). The Halobacteriaceae. In The Bacteria, a Treatise on Structure and Function, vol. VIII, pp. 171-206. Edited by I. C. Gunsalus, C. R. Woese \& R. S. Wolfe. San Diego: Academic Press.

Mancinelli, R. L. \& Hochstein, L. I. (1986). The occurrence of denitrification in extremely halophilic bacteria. FEMS Microbiol Lett 35, 55-58.

Marmur, J. (1961). A procedure for the isolation of deoxyribonucleic acid from microorganisms. J Mol Biol 3, 208-218.

Marmur, J. \& Doty, P. (1962). Determination of the base composition of deoxyribonucleic acid from its thermal denaturation temperature. J Mol Biol 5, 109-118.
Sasser, M. (1990). Identification of bacteria by gas chromatography of cellular fatty acids, MIDI Technical Note 101. Newark, DE: Microbial ID.

Schleifer, K. H. \& Kandler, O. (1972). Peptidoglycan types of bacterial cell walls and their taxonomic implications. Bacteriol Rev 36, 407-477.

Sehgal, S. N. \& Gibbons, N. E. (1960). Effect of some metal ions on the growth of Halobacterium cutirubrum. Can J Microbiol 6, 165-169.

Smibert, R. M. \& Krieg, N. R. (1981). General characterization. In Manual of Methods for General Microbiology, pp. 409-443. Edited by P. Gerhardt, R. G. E. Murray, R. N. Costilow, E. W. Nester, W. A. Wood, N. R. Krieg \& G. B. Phillips. Washington, DC: American Society for Microbiology.

Thompson, J. D., Gibson, T. J., Plewniak, F., Jeanmougin, F. \& Higgins, D. G. (1997). The CLUSTAL_X windows interface: flexible strategies for multiple sequence alignment aided by quality analysis tools. Nucleic Acids Res 25, 4876-4882.

Ventosa, A., Quesada, E., Rodriguez-Valera, F., Ruiz-Berraquero, F. \& Ramos-Cormenzana, A. (1982). Numerical taxonomy of moderately halophilic Gram-negative rods. J Gen Microbiol 128, 1959-1968.

Ventosa, A., Nieto, J. J. \& Oren, A. (1998). Biology of moderately halophilic aerobic bacteria. Microbiol Mol Biol Rev 62, 504-544. 